\title{
Study of Public Service Communication Activities in Response to the Psychological Crisis on COVID-19 Pandemic at GPIB Ekklesia BUNR
}

\author{
Samantha Luhukay ${ }^{1 *}$ \\ ${ }^{1}$ Master of Communication, Universitas Atma Jaya Yogyakarta, Yogyakarta 55281, Yogyakarta \\ *Corresponding author. Email: samanthaluhukay14@gmail.com
}

\begin{abstract}
The public communication in the middle of the COVID-19 pandemic is currently the responsibility of each organization. Belief problems regarding the coverage of pandemic issues in the media to how to deal with pandemic situations need to be communicated periodically by the Organization to prevent irregularities in the behavior of members of the organization. The concept of public service communication conveyed and represented by religious leaders, as a form of anticipation of the psychic crisis to receive the congregation, can live alongside this situation. This research uses the type of case study research with a qualitative approach and an expreslanatical case study approach. In principle, the status of Knowledge and Thrones successfully establishes public opinion. The Opinion leader takes over the role of continuous communication related to their responsibilities but also as a form of audience confidence in him following the theory of the Two-step Flow Model assumed by Katz and Lazarfief before. The Two-Step Flow theory is more of a mass media that is considered effective in presenting communicators as the leader of public communication regarding hot topics in the media. Pandemic COVID-19 is an interesting case to be discussed because it relates to the media conditions, the audience (community), and the opinion leader. There are three findings found in this study: (1) The media message received by the audience; (2) Alacrity and feedback in delivering the situation to the congregation, through the opinion leader; and (3) the audience situation before, during and after obtaining the opinion leader's direction. The three are interconnected and can be adopted by other organizations.
\end{abstract}

Keywords: Coronavirus, Media, Public communication, Religion.

\section{INTRODUCTION}

Public communication in the middle of the COVID-19 pandemic is currently the responsibility of each organization. This journal takes a communication perspective on the Protestant church in the western part of the Ekklesia International Airport I Gusti Ngurah Rai (GPIB Ekklesia BUNR), the church on the island of Bali dominated by $60 \%$ of the congregation working in the tourism and immigration sector [1]. The problem of trust in the preaching of pandemic issues in the media to how to deal with pandemic situations need to be communicated periodically by the Organization to prevent irregularities in the behavior of the congregation in the GPIB Ekklesia. This condition had a psychological impact on the congregation; it was conveyed by Jeannate Rade [2] General secretary of the GPIB Ekklesia Church. The psychic crisis of the congregation influences the way the opinion leader is involved in responding to this.
The coverage of the COVID-19 pandemics affects public service communication concepts. Public service communications were delivered and represented by religious leaders, priest, and Synod of GPIB (a larger scoop in the structure of the church). Pastor Semuel A. Z. Karinda as the Chairman of the Church Assembly (Ketua Majelis Jemaat - KMJ) GPIB Ekklesia BUNR is the opinion leader when communicating the situation facing COVID-19 pandemic to the process of acceptance that the congregation can coexist with the current situation.

This case involves the two-phase communication theory or the 'Two-Step Model Theory' to see the effects of exposure on the media and its impact when received by the opinion leader and the public. Williams [3], seeing the characteristics of theories in social life such as religion and social classes, was influenced by several media factors used with the reason to change one's courage.

The problem formulation in research is how public service communication activity responds to the psychic crisis at GPIB Ekklesia Bali. The purpose of research is to 
know the activity of public service communication when responding to the psychic crisis related to the COVID-19 pandemic case in GPIB Ekklesia Bali.

\section{LITERATURE REVIEW}

Researchers took two referral journals as comparative research: firstly, the Journal of Communication Science of Universitas Padjadjaran in 2014. The first research was written by Priyo Subekti, Hanny Hafiar, Trie Damayanti, and FX Ari Agung P, entitled 'Health Communication Campaign through Multi-Step Flow Communication Model to Suppress the Early Age Wedding Number in Urban Communities in Bandung District' using a qualitative descriptive approach to get an idea or description of the object or phenomenon that causes young marriage among teenagers in Urban communities in Bandung Regency [4]. Subekti along with other researchers [4] reviews how health communication campaigns through a multi-step flow communication model to suppress the number of early childhood marriage in urban communities in Bandung District. The research took the entrants into the area of the industry getting married at a young age or doing an early childhood marriage as the research unit.

Secondly, the research journal compiled by Lukiati Komala, Hanny Hafiar, Trie Damayanti, Lilis Puspitasari, took the title of 'Implementation of Health Communication Model Two-Step Flow Communication in Spreading Maternal and Fetus Health Information through the Shamans in West Java' [5]. The research used mixed quantitative and qualitative methods. Komala and other researchers [5] studied the process of collecting quantitative data using surveys and qualitative data obtained by observation and interview. The purpose of research was to implement the Two-Step Flow Communication model to disseminate health information from medical personnel to the child shamans who are subsequently spearheaded for the provision of maternal and fetal health services in the West Java region. It was assumed in the research of Komala that the dissemination of information to the public by the Government is represented by the local health department through medical personnel such as doctors and midwives can be done through the shamans. This is a reference for further research because of the belief in the existence of shamans who are still strong enough among the rural community.

\section{METHODS}

This research was conducted using case study type with a qualitative approach. In this research, researchers used an expreslanatical case study approach. An exploited case study is a case study approach leading to research questions of 'how' and 'why'. According to Yin [6], this is because the question is related operationally to demand for tracking its own time, not just the time of its appearance.
The research also used case studies with intertwined design, i.e. researchers can cope with changes in orientation direction that can occur even while research is ongoing. The subject of the study was chosen based on several criteria to be used as a speaker, among others: (1) the active congregation in GPIB Ekklesia Bali aged 20-25 years, aged $26-35$ years and aged $36-69$ years. This is due to the consideration of the age of the congregation 30 years and above has a more risk level of psychic crisis than the age below 20 years; and (2) citizens of congregations, priests, and assemblies serving more than five years. Other services were based on the influence of public service communication for the congregation. Furthermore, the subject selection is also based on the experience of church at GPIB Ekklesia Bali and considers the position or position of interest within the organization.

The technique of collecting data used in this research was in-depth interviews, one of the data collection techniques involving humans as the subject of research, which relates to the reality or symptoms to be selected for further investigation [7]. Meanwhile, according to Berger [8], Interviews are conversations between researchers or someone wishing to obtain information and informant or someone assumed to have important information about an object. In addition this research also used observation to collect data; this was done by observing and recording the object in place of the happening or the continuity of the event. Systematic observation and recording of the symptoms seen in the research object [9], the type of observation conducted by researchers in the study was direct non-participatory observation.

Technique of data analysis used in this research was the one suggested by to Miles and Huberman encompassing data reduction, data presentation and draw conclusion or data verification. In the first phase, data reduction is that this process will be more conical to the necessary parts to facilitate the researcher's conclusion. In the second stage, the data presented will be more conical to the necessary parts to facilitate the researcher's conclusion. Last phase is the draw conclusion or data verification, the process relying solely on the data owned by the researcher, the theory used, and the results of its interpretation of the data [10].

\section{RESULTS AND DISCUSSIONS}

\subsection{Results}

Data findings related to research conducted by researchers, based on the basic assumption that communication is in two stages, also saw the active work of the media in processing and responding to media messages on a flat. Theoretically, it is noteworthy that mass communication theory states that audiences can directly respond to the message they receive [3].

Researchers get an important record in the data discovery process, that the two-stage communication 
theory becomes particularly relevant during non face-toface situations.

\subsubsection{Media Messages Received by the Audience}

Researchers collected the data in the GPIB Ekklesia BUNR through online media since the start of the COVID19 pandemics in Indonesia. This is in line with the study conducted by Hendriani[1], as a church and HR Administrator Staff in GPIB Ekklesia BUNR, finding that the media coverage of the pandemic is obtained by the Church periodically from broadcast media, social media, and other online news media.

"GPIB was briefly highlighted as the Bogor cluster. Being a challenge for GPIB, there was an annual synod conference in Bogor. [...] Yes indeed the trial was happening in Bogor and GPIB gave the correct information in the national media. The Media helped explain that GPIB here is also a victim [...] which is also revealed mayor of Bogor, chairman of the MPR $R I$, and all the priests in other clusters. Some participants were infected but, now healed and already active normally. The rest is okay" [11]

On the other hand, researchers also found the symptoms of anxiety submitted by Jeannate Rade [2], as a church and served as the assembly of the Church in GPIB Ekklesia BUNR, stating that it conveys the condition of the church in its service environment.

"The condition of the church in a sector service environment of one to ten different people, most of them are experiencing confusion about the information received in the media and impact on its daily life. This is because it happens directly heavily to us. Now many people cannot work and even afraid of meet other people, and so do not have friends' stories and earnings." [2]

The condition is also supported by other psychical symptoms due to the loss of work and is difficult to communicate with others due to social restrictions and recommendations to stay at home alone during this pandemic period.

"The impact occurring is obviously because in Bali the main source of livelihood is tourism. Our church, has a congregation from Benoa, Nusa Dua, Jimbaran, Kuta, partly in Dalung, all the work in the field of tourism. All impacted. Work is lost, the economy gradually decreases." [11]

\subsubsection{Alacrity and Feedback in Delivering the Situation to the Congregation, through the Opinion Leader}

Researchers, in this regard, take notice of many situations and obtain information that the pastor periodically conveys in his public service communication to the congregation. The implementation was done through video conferencing during the announcement of the closure of the synagogue during the COVID-19 pandemic to an indefinable deadline. This condition becomes the meeting point between the intercessions which is the official feedback of the pastor Semuel A. Z. Karinda as the Chairman of the Church Assembly (KMJ).

"The church's understanding of the government is the Messenger of God to govern mankind. Well, that means, any policy taken by the Church regarding the COVID-19 must follow the government's recommendation. Yes, it relates to keeping the distance, washing clean hands, and so on." [11]

This is in line with what Vevi Hendriani has presented, that church support to the Government has been reflected in the indecisiveness and preventative efforts to face the COVID-19 pandemic.

"The Leader in the church as pastor, we did the protocol. GPIB takes a perceptive stance to support the government to stop this coronavirus" [1].

The supporting step is also conveyed to the congregation through the online communication media conducted by the public service communications periodically by the Pastor Semuel, related to the submission of God's Word through sermons and meditations via WhatsApp and others.

"First, following the timing of instruction from the governor was dropped on March 12, 2020, we held a meeting with the entire presbyter assembly in the church. We agreed to explain online to the congregation because if you cannot encounter them one by one. It is a tough decision for us to run [...] Yes, we've ever done that way, the house worship time was the Bali bombings 1 and 2, then there was Nyepi as well. But it's just a minute and not long. " [11]

The self-adjusting of the congregation in this pandemic situation requires special encouragement and effort for the church components, especially the pastor to give a sense of calm to the congregation; this is characterized by material assistance and moral encouragement.

"The church is here to help. This is called the caritative deacon meaning no longer gives an understanding of earning a living. But, we should give you an example of that kind of love. We hope that after this pandemic begins to diminish the congregation can already get the work of the caritative deacon to be over." [11]

"We must be optimistic that this pandemic will end. We are also ready to attend and to help governments deal with the current conditions especially." [11]

\subsubsection{The Audience Situation Before, During and After Obtaining the Opinion Leader's Direction}

In the interview, three speakers of the researcher found a significant behavioral linkage in the opinion leader when responding to the media to resubmit to the audience. In actual condition, according to the narrative of Vevi Hendriani, the GPIB management, especially GPIB 
Ekklesia, has tried to convey very well to the congregation. The Regulation for order and health together is also sought continuously for the tranquility of worship activities.

"Adapting to the environment is done step by step, cooperation with all parties. Most of them work with church employees to support the government in promoting social distancing, hand washing, and doing other hygiene protocol." [1]

This condition also supports the communication process of public servants to the congregation. Researchers observe the high tendency to socialize, considering that the church environment is very close to the fellowship and gathering event as a routine activity. The pastor as the opinion leader also recognizes the social change since the COVID-19 pandemics taking place; therefore it is necessary to understand that this condition will be only temporary and the congregation can deal with it together by following the health protocols and recommendations that have been established by the government.

"We are confused convey to the congregation. But because of technology and the media, we can finally

deliver it to the congregation as well. Well, that's what I said earlier that this COVID-19 pandemic ended up being a momentum of social change in the community especially in the church." [11]

The last findings of the researcher's data led to the process of adapting the congregation to the current conditions due to the novelty in worship communication and the influence of the social environment therein.

"Yes, during this time, the communication of public service in the church is always done, because we remember the condition of the church that is similar to us in the church office. It does not easily understand such situation. It is difficult, especially for those who lost their jobs and activities changed. When I was in the church to the congregation, I saw that they had a new hobby, some of them like to plant, and the others learn to cook." [2]

\subsection{Discussion}

First, the media message is received by the audience. Researchers see the role of media in shaping the psychical crisis process of the congregation. The psychic crisis is one of the psychological problems that can be experienced by everyone regardless of age and time. The psychic crisis begins with trauma. According to Chaplin [12], it is said that trauma is physical and psychical wound. Trauma can cause an anxiety disorder. Meanwhile, according to Strauser, et al [12], trauma is an event involving an individual indicated with an incident allowing wound or death, so that a feeling of being terrorized and discouraged grows. It can be concluded that trauma is an event involving an individual causing an incident that could affect the physical, physical, or psychic.

The data findings in the field are in accordance with the presentation of the concept of psychic crisis. The church feels excessive worries and anxiety due to the loss of work and cannot socialize. This condition was worse when worship was done at home. Herdiana Vevi [1] said that the condition was not directly acceptable to all the churches because many of them were still active to confirm the truth. It is a sign of distrust about the situation. On the other hand, Pastor Semuel also said that GPIB Ekklesia took an active role in supporting the government by stopping worship and periodically as an opinion leader to communicate the situation to his congregation [11].

Secondly, an alacrity and feedback in delivering the situation to the congregation, through the opinion leader. The study used 'Two-Step Model Theory' based on models described by Lazarfeld and Elihu Katz assessing people's reactions to media messages mediated by interpersonal communication with members of the social environment [13]. This theory sees the meaning of a person's membership in a different social group that has a greater influence on decision-making and directly implicates the person's behavior from the mass media and/or information obtained. Communication in two stages also sees active work of media in processing and responding to media messages in a flat. Theoretically, this is important to keep in mind about the basic assumption of mass communication theory is that audiences can respond directly to messages they receive.

The findings of the data refer to the focus of research objects relating to public communication on the opinion leaders, in this case, religious leaders, clergymen, and assembly when responding to the psychical crisis of the church in the Protestant Church of Indonesia in the West (GPIB) Ekklesia Bali. Researchers involve aspects of communication theory, "Two-Step Model theory" Media effects by looking at the effects of media coverage on COVID-19, and its impact on communicators in public service (Reverend) to be addressed to his congregation.

The pastor as an opinion leader does not directly state the situation occurring in the field. As presented by Pastor Semuel [11], since the first order of the governor of Bali to shut down the house of church components, they do not yet understand the situation that happened. In that situation as an opinion leader of the pastor, Semuel conducted evaluation periodically by checking the truth on some media and presenting direct speaker from health to convey his appeal to the congregation in the sermon as a part of communication public service by GPIB Ekklesia BUNR.

Two-step flow model

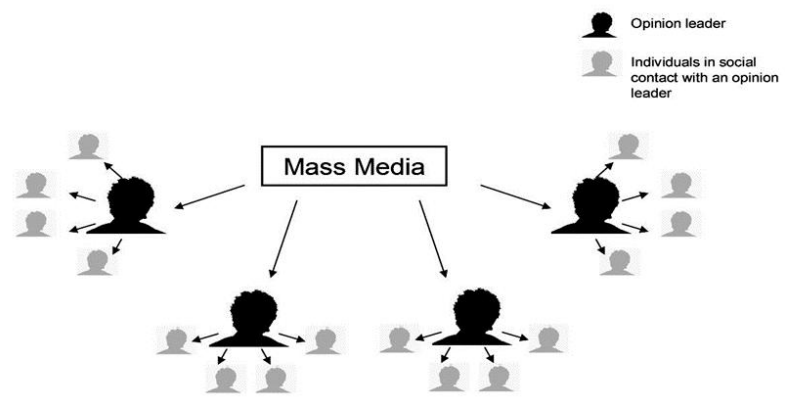

Figure 1 Two-step Flow Model 
The Model depicted above explains that Lazarfeld and Elihu Katz assessed the person's reaction to media messages mediated by interpersonal communication with members of his social environment [13]. This theory, if seen in the research conditions in GPIB Ekklesia BUNR, is very relevant because the opinion leader can see the meaning of a person's membership in a different social group that has a greater influence on decision making and directly implicates the behavior of the person from the mass media and/or information obtained.

The theory is true in GPIB Ekklesia BUNR, because communication in two phases can see the active work of the media in processing and responding to media messages on a flat. Other conditions occurring impact the current situation with marked changes in the behavior of the church during the COVID-19 pandemic. Previous researchers mentioned the existence of indications of the psychical crisis of the congregation, evidenced in the findings of data, and in the discussion where the reasons for the psychic crisis change occurring can be found, because of the ongoing public communication service.

Finally, the process of handling the psychic crisis can be done by the congregation through utilizing the mass media and social media. The pastor as an opinion leader can communicate the public service by continuing to consider the Government's recommendation (as presented in media coverage to the present time). Furthermore, according to JeannateRade [2], it is characterized by a change in the behavior of the congregation that initially did not believe in the physical distancing process and social distancing until the closure of the synagogue for a while.

\section{CONCLUSION}

First, the media message received by the audience is an important thing that anyone cannot help. This condition is explained in the findings and discussion of the problem showing that the media plays an active role in public opinion. Audiences or audiences can provide a free view of a news story and can directly interpret it freely. On the other hand, media messages can also result from many causes due by various events. This can be seen from the COVID-19 pandemic coverage received directly by the GPIB Ekklesia BUNR congregation. But the positive side of the media coverage cannot be eliminated because it is directed to convey the government message to the public organizations in order to be able to comply with health and safety protocols during the COVID-19 pandemic period has not ended.

Secondly, an error and feedback in delivering the situation to the congregation, through the opinion leader. Researchers expressed his idea of the level of preparedness and the feedback process on the discussion and found the red thread that the communication message conveyed by the opinion leader in an organization is important and undisputed. The pastor also became a source of information for the congregation even though they had obtained information through many media. The GPIB Ekklesia BUNR Church actively sought to know the correctness of the information on the pastor and also took an active role in disconnecting the pandemic chains.

Third, the audience situation before, during, and after obtaining the opinion leader's referral. The current situation marked the change in the behavior of the congregation during the COVID-19 pandemic. Previously researchers mentioned the presence of indications of the psychic crisis of the congregation, this is evidenced in the findings of the data and the discussion can be found reasons for the psychic crisis change occurred because of the ongoing public communication service.

Finally, these three processes are interconnected and can be concluded that the handling of the psychic crisis can be handled by the church by utilizing the mass media and existing social media, as well as the pastor as the opinion leader, can communicate back the public service by continuing to pay attention to government recommendation The active role of public service communication amid the COVID-19 pandemic situation is very necessary especially regarding community mental health problems. This important point should always be remembered, as extraordinary events can have a diverse impact on the affected audience. COVID-19 Pandemic needs to gain special attention because it may not end for a long period and is an important record, especially in public organizations to maintain the welfare and mental health of the people periodically. The Opinion leader takes over the role of continuous communication related to their responsibilities but also as a form of audience confidence in him following the theory of the Two-step Flow Model assumed by Katz and Lazarfief before.

\section{ACKNOWLEDGMENT}

This work was supported by Universitas Atma Jaya Yogyakarta, Communications Sciences Magister, and the Protestant church in the western part of the Ekklesia International Airport I Gusti Ngurah Rai (GPIB Ekklesia BUNR).

\section{REFERENCES}

[1] Hendriani, Veviana. Personal Interview. 2020.

[2] Rade, Jeannate. Personal Interview. 2020.

[3] Williams, Kevin. Understanding Media Theory. London: Oxford University Press Inc. 2003.

[4] Subekti, Priyo. KampanyeKomunikasi Kesehatan Melalui Model Multi Step Flow Communication DalamMenekan Angka PernikahanUsia Dini Pada 
Masyarakat Urban Di Kabupaten Bandung. JurnalSosiohumaniora, Volume 16 No. 3 November 2014: $263 \quad-\quad 269 . \quad$ DOI : https://doi.org/10.24198/sosiohumaniora.v16i3.5766

[5] Komala, Lukiati. Implementasi Model Komunikasi Kesehatan Two Step Flow Communication DalamMenyebarkanInformasi Kesehatan Ibu Dan JaninMelalui Para Dukun Beranak di Jawa Barat. JurnalKomunikasiKAREBA : Vol. 3, No. 1 Januari Maret 2014.

DOI :http://dx.doi.org/10.31947/kjik.v3i1.569

[6] Yin, Robert K. StudiKasus: Desain \&Metode. Jakarta: PT. Raja GrafindoPersada. 2002

[7] Pawito. PenelitianKomunikasiKualitatif. Yogyakarta : PT. LKiS Pelangi Aksara. 2007.

[8] Kriyantono, Rachmat. (2008). Teknik PraktisRisetKomunikasi: DisertaiContohPraktisRiset Media, Public Relations, Advertising, KomunikasiOrganisasi, KomunikasiPemasaran. Jakarta: KencanaPrenada Media Group. 2008. DOI :

[9] Margono. MetodologiPenelitian Pendidikan. Jakarta: RinekaCipta. 1997.

[10] Sugiyono. Metodepenelitian; kuantitatif, kualitatif, dan R\&D. Bandung :PenerbitAlfabeta. 2016.

[11] Karinda, Semuel. Personal Interview. 2020.

[12] Rayahu, Sestuningsih. KonselingKrisis: SebuahPendekatanDalamMereduksiMasalahTraumatik Pada Anak Dan Remaja. Jurnal Pendidikan Volume 2 Nomor $\quad 1 \quad$ Tahun 2017. DOI :http://dx.doi.org/10.26740/jp.v2n1.p65-69

[13] Postelnicu, Monica. 2014. Two-step flow model of communication. Diaksesdari https://www.britannica.com/topic/two-step-flow-modelof-communication. $2014 . \quad$ DOI tps://doi.org/10.1086/266687 